\title{
Effect of retinoid $X$ receptor- $\alpha$ nuclear export inhibition on apoptosis of neurons in vivo and in vitro
}

\author{
YINGCHUN LIU $^{1}$, JIANGGUO TANG ${ }^{1}$, XIAOXIAO GAO ${ }^{1}$, MIN WANG $^{1}$, JIE SHEN $^{2}$ and XIAOQING YOU ${ }^{1}$ \\ ${ }^{1}$ Department of Cell Biology and Genetics, School of Basic Medical Sciences, Fujian Medical University, Fuzhou, \\ Fujian 350108; ${ }^{2}$ Cadre Ward, Fujian Medical University Union Hospital, Fuzhou, Fujian 350001, P.R. China
}

Received November 27, 2015; Accepted January 13, 2017

DOI: $10.3892 / \mathrm{mmr} .2017 .6766$

\begin{abstract}
Alzheimer's disease (AD), which is characterized by excessive apoptosis of neurons, is considered to be a global public health crisis. Retinoid-induced apoptosis is dependent on the orphan nuclear receptor Nur77, a transcription factor that is expressed predominantly in brain tissues. Nur77 nuclear export requires retinoid $\mathrm{X}$ receptor- $\alpha(\mathrm{RXR} \alpha)$ as a carrier. However, the involvement of Nur77 in mediating $\beta$-amyloid (A $\beta$ )-induced neuronal apoptosis has not yet been elucidated. The primary aim of the present study was to investigate the potential of Nur77 in A $\beta$-induced neuron apoptosis, and to evaluate the effect of $\operatorname{RXR} \alpha$ nuclear export inhibition on neuronal apoptosis. Mouse neuroblastoma Neuro-2a (N2a) cells and mouse hippocampi were treated with $A \beta_{25-35}$ or $A \beta_{25-35}$ combined with a RXR $\alpha$ ligand, 9-cis-retinoid acid (9-cis-RA), while untreated cells and mice served as controls. The expression of RXR $\alpha$ and Nur77 was determined using western blotting and reverse transcription-quantitative polymerase chain reaction analyses, and the translocation of RXR $\alpha$ and Nur77 was detected using confocal microscopy. In addition, the apoptosis and viability of N2a cells was detected using flow cytometry and MTT assays, respectively, and the expression of B cell lymphoma 2 (Bcl-2) and Bcl-2 associated X (Bax) was quantified by western blotting. No significant alterations in the protein or mRNA expression levels of $\mathrm{RXR} \alpha$ and Nur77 in N2a cells or mouse hippocampi among the three groups were observed. $A \beta_{25-35}$ treatment resulted in elevated cytoplasmic protein ratios of RXR $\alpha$ and Nur77 in N2a cells when compared with controls, while combined treatment with $\mathrm{A} \beta_{25-35}$ and 9-cis-RA reduced cytoplasmic protein ratios of RXR $\alpha$ and Nur77 to 6.67 and 5.44\% in N2a cells, respectively. The MTT assay results revealed a significant reduction in the viability of $\mathrm{N} 2 \mathrm{a}$ cells following treatment with $\mathrm{A} \beta_{25-35}$ for $24 \mathrm{~h}$
\end{abstract}

Correspondence to: Dr Xiaoqing You, Department of Cell Biology and Genetics, School of Basic Medical Sciences, Fujian Medical University, 1 Xueyuan Road, Fuzhou, Fujian 350108, P.R. China E-mail: yxqtr@163.com

Key words: Alzheimer's disease, $\beta$-amyloid, 9-cis-retinoid acid, retinoid $\mathrm{X}$ receptor- $\alpha$, Nur77, apoptosis, nuclear export when compared with the controls, while the viability of $\mathrm{N} 2 \mathrm{a}$ cells treated with $A \beta_{25-35}$ plus 9-cis-RA significantly increased from 53.65 to $84.10 \%$. Western blotting revealed elevated Bax expression and reduced $\mathrm{Bcl}-2$ expression in $\mathrm{A} \beta_{25-35}$-treated $\mathrm{N} 2 \mathrm{a}$ cells when compared with controls, while combined treatment with $\mathrm{A} \beta_{25-35}$ and 9-cis-RA recovered Bcl-2 expression from 0.46-fold in cells treated with $\mathrm{A} \beta_{25-35}$ alone to 2.44-fold (relative to the control) and decreased Bax expression from 2.52-fold in cells treated with $A \beta_{25-35}$ alone to 0.99-fold (relative to the control). Flow cytometry analysis revealed that the apoptotic rate of untreated $\mathrm{N} 2$ a cells was $4.36 \%$, while a $15.1 \%$ apoptotic rate was detected in cells exposed to $A \beta_{25-35}$ for $24 \mathrm{~h}$ and a $\sim 5.31 \%$ apoptotic rate was observed in $\mathrm{N} 2$ a cells treated with $\mathrm{A} \beta_{25-35}$ plus 9-cis-RA. In conclusion, treatment with $\mathrm{A} \beta_{25-35}$ or $\mathrm{A} \beta_{25-35}$ plus 9-cis-RA demonstrated no significant effect on the protein and mRNA expression levels of RXR $\alpha$ and Nur77. In addition, inhibition of $\mathrm{RXR} \alpha$ nuclear export reduced neuronal apoptosis. The results of the present study may provide novel insight into the development of novel anti-AD agents.

\section{Introduction}

Alzheimer's disease (AD) is the most common form of dementia, and is a complex disease characterized by the formation of senile plaques and neurofibrillary tangles composed of tau amyloid fibrils. These are associated with synapse loss and neurodegeneration, which results in memory impairment and additional cognitive problems (1). It has been estimated that $0.40 \%$ of the world population (26.6 million people) were living with $\mathrm{AD}$ in 2006, and that the prevalence rate would triple and the absolute number of individuals with the disease would quadruple by the year 2050 (2). Therefore, this disease is considered to be a global public health concern and presents a challenge due to its high prevalence and the burden of the disease (3). However, to date, there are no available treatments that reduce the progression of $\mathrm{AD}$ (4). Excessive apoptosis of neurons is a notable pathological feature of AD (5). $\beta$-amyloid $(\mathrm{A} \beta)$, the major component of senile plaques, has been demonstrated to contribute to neuronal apoptosis (6). Therefore, anti-apoptotic therapy may be a promising treatment for AD (7-9).

Apoptosis typically occurs via the extrinsic or intrinsic pathway in vertebrate cells (10). It has been demonstrated that the orphan nuclear receptor Nur77, also known as TR3 
or nerve growth factor IB, is a transcription factor expressed predominantly in brain tissues (11) that may be involved in the intrinsic mitochondrial-initiator pathway (12). Nur77 was reported to migrate into the mitochondria to induce conformational alterations in B cell lymphoma-2 (Bcl-2) and contribute to the induction of apoptosis in multiple organs (13). However, Nur77 nuclear export requires retinoid $\mathrm{X}$ receptor- $\alpha(\mathrm{RXR} \alpha)$ as a carrier (14).

$\mathrm{RXR} \alpha$, a member of the nuclear receptor superfamily, regulates the transcription of target genes by binding to DNA response elements (15). It has been demonstrated that $\mathrm{RXR} \alpha$ forms heterodimers with additional members of the steroid/thyroid/retinoid receptor family, including Nur77 (16). Notably, RXR $\alpha$ may additionally be involved in multiple biological processes, including differentiation, inflammation and apoptosis, by translocating from the nucleus to the cytoplasm (17-19). In addition, a previous study revealed that retinoids were unable to induce apoptosis in Nur77 null thymocytes, suggesting that retinoid-induced apoptosis was dependent on Nur77 (20).

It has been demonstrated that Nur77 nuclear export may induce apoptosis of T-cell hybridomas and immature thymocytes (21), as well as various types of cancer cells (22-24); however, the exact function of Nur77 requires further elucidation. In addition, the involvement of Nur77 in A $\beta$-induced neuronal apoptosis remains unclear. The primary aim of the present study was to examine the potential involvement of Nur77 in A $\beta$-induced neuronal apoptosis, and to evaluate the effect of $\operatorname{RXR} \alpha$ nuclear export inhibition on neuronal apoptosis.

\section{Materials and methods}

Ethical statement. All animal experimentation was performed in accordance with the recommendations of the Guidelines for the Care and Use of Laboratory Animals, (Ministry of Science and Technology of the People's Republic of China, Beijing China). The present study was approved by the Ethics Review Committee of Fujian Medical University (permission no. FYD2013-00127).

Drugs. A $\beta_{25-35}$ powder (Sigma-Aldrich; Merck KGaA, Darmstadt, Germany) was dissolved in $\mathrm{ddH}_{2} \mathrm{O}$, and incubated at $37^{\circ} \mathrm{C}$ for one week. 9-cis-retinoid acid (9-cis-RA; Sigma-Aldrich; Merck KGaA) was diluted in dimethyl sulfoxide. $A \beta_{25-35}$ and 9 -cis-RA stock solutions were stored at $-80^{\circ} \mathrm{C}$ for use in subsequent experiments.

Cell culture and treatment. The mouse neuroblastoma Neuro-2a (N2a) cell line was purchased from the Cell Bank of Type Culture Collection of Chinese Academy of Sciences (Shanghai, China). Cells were seeded onto 3 cell culture dishes (10 $\mathrm{mm}$ in diameter) at a density of $1.6 \times 10^{5}$ cells/dish, and were cultured in 50\% Dulbecco's modified Eagle's medium (Mediatech; Corning Incorporated, Corning, NY, USA) and 50\% Opti-minimum essential medium (Thermo Fisher Scientific, Inc., Waltham, MA, USA) supplemented with $5 \%$ fetal bovine serum (Hyclone; GE Healthcare Life Sciences, Logan, UT, USA). N2a cells were assigned to the following three groups: i) The $A \beta_{25-35}$ treatment group, where cells were treated with $25 \mu \mathrm{mol} / 1 \mathrm{~A} \beta_{25-35}$ solution for $24 \mathrm{~h}$; ii) the $\mathrm{A} \beta_{25-35}-9$-cis-RA treatment group, where cells were incubated in $0.1 \mu \mathrm{mol} / 19$-cis-RA solution for $12 \mathrm{~h}$, followed by treatment with $25 \mu \mathrm{mol} / 1 \mathrm{~A} \beta_{25-35}$ solution for $12 \mathrm{~h}$; iii) Control group, where cells were treated with the same volumes of $\mathrm{ddH}_{2} \mathrm{O}$. The $\mathrm{N} 2 \mathrm{a}$ cells were then maintained at $37^{\circ} \mathrm{C}$ in a humidified incubator with $5 \% \mathrm{CO}_{2}$ for $24 \mathrm{~h}$, before they were harvested.

Animal grouping. A total of 15 male,4-month-oldC57/BL6 mice (Experimental Animal Center of Fujian Medical University, Fuzhou, China), each weighing $20 \mathrm{~g}$, were group-caged at a room temperature of $22^{\circ} \mathrm{C}$ and humidity of $55 \pm 10 \%$, with 10 mice in each cage. All mice were kept under a $12 \mathrm{~h}$ light/dark cycle with free access to food and water. Mice were randomly assigned into three equal groups of five as follows: The $A \beta_{25-35}$ treatment group, the $A \beta_{25-35}-9$-cis-RA treatment group and the sham-operation group. The mice were anesthetized for $3 \mathrm{~h}$ with $10 \%$ chloral hydrate (Tianjin Beilian Fine Chemical Products Development Co., Ltd., Tianjing, China) at a dose of $300 \mathrm{mg} / \mathrm{kg}$ by intraperitoneal injection. Following excision of scalp cutaneous tissue, a bar hole was created at $2 \mathrm{~mm}$ posterior to the bregma and $2.5 \mathrm{~mm}$ lateral from the midline. Mice in the $\mathrm{A} \beta_{25-35}$ treatment group were treated with $1 \mu \mathrm{l} A \beta_{25-35}$ solution $\left(A \beta_{25-35}\right.$ powder was dissolved in physiological saline to yield a $2 \mu \mathrm{g} / \mu \mathrm{l}$ solution and incubated at $37^{\circ} \mathrm{C}$ for 7 days) by inserting a microsyringe through the bar hole to reach the hippocampus. Mice in the $\mathrm{A} \beta_{25-35}-9$-cis-RA treatment group were treated with a mixture $\left(1 \mu \mathrm{l}\right.$ total) of $\mathrm{A} \beta_{25-35}(2 \mu \mathrm{g} / \mu \mathrm{l})$ and 9-cis-RA solutions $(1 \mu \mathrm{g} / \mu \mathrm{l})$, while mice in the sham-operation group were treated with the same volume of physiological saline. At $24 \mathrm{~h}$ after surgery, the mice were anesthetized with $10 \%$ chloral hydrate $(300 \mathrm{mg} / \mathrm{kg}$ ) and subjected to cardiac perfusion with $4 \%$ paraformaldehyde, and approximately 15 to $20 \mathrm{mg}$ mouse hippocampal tissues were excised, divided into sections, lysed in radioimmunoprecipitation (RIPA) lysis solution (Beyotime Institute of Biotechnology, Haimen, China), heated in a microwave for $5 \mathrm{sec}$, vortexed for $30 \mathrm{sec}$ $(1,500 \mathrm{rpm})$, incubated on ice for 15 to $30 \mathrm{~min}$ and centrifuged at $4^{\circ} \mathrm{C}$ and $13,000 \mathrm{x} \mathrm{g}$ for $5 \mathrm{~min}$. The supernatant was transferred to sterile Eppendorf tubes for subsequent experiments. Mice that stopped moving and developed complete muscular relaxation were considered to be in deep anesthesia.

Western blotting assay. Cell and hippocampal tissue lysates were prepared in RIPA lysis buffer as described previously (25). The nuclear and cytoplasmic extracts from N2a cells and mouse hippocampal tissues were prepared using the Nuclear Extraction kit (Merck KGaA). Equal quantities of protein $(25 \mu \mathrm{g} /$ per lane) were resolved on a 4-20\% Tris-glycine gel, and transferred onto polyvinylidene difluoride membranes (EMD Millipore, Billerica, MA, USA). The membranes were blocked for $1 \mathrm{~h}$ in $0.05 \%$ TBS-Tween-20 (TBST) containing 5\% skim milk at room temperature, and subsequently incubated at $4^{\circ} \mathrm{C}$ overnight with the following primary antibodies: Rabbit anti-Bcl-2 (cat. no. D160117; 1:500; Sangon Biotech Co., Ltd.; Shanghai, China), rabbit anti-Bcl-2 associated X (Bax; cat. no. D120073; 1:500; Sangon Biotech Co., Ltd.), rabbit anti-RXR $\alpha$ (cat. no. sc-553; 1:1,000; Santa Cruz Biotechnology, Inc., Dallas, TX, USA) and rabbit anti-Nur77 (cat. no. sc-5569; 1:1,000; Santa 
Cruz Biotechnology, Inc.), while rabbit anti- $\beta$-actin (13E5) antibody (cat. no. 4970; 1:3,000; Cell Signaling Technology, Inc., Danvers, MA, USA), rabbit anti-poly (ADP-ribose) polymerase (cat. no. 9532; 1:2,000; Cell Signaling Technology, Inc.) and rabbit anti-heat shock protein 60 (cat. no. ab46798; 1:2,000; Abcam, Cambridge, UK) served as loading controls. After washing in TBST, the membranes were incubated with the goat anti-rabbit horseradish peroxidase-conjugated IgG antibody (cat. no. 7074; 1:8,000; Cell Signaling Technology, Inc.) at room temperature for $1 \mathrm{~h}$. Detection of proteins was performed by using an EasyBlot ECL kit (Sangon Biotech Co., Ltd.) according to the manufacturer's protocol. The band density was quantified using ImageJ 1.49 (National Institutes of Health; Bethesda, MD, USA). Experiments were performed in triplicate.

Reverse transcription-quantitative polymerase chain reaction (RT-qPCR). Total RNA was prepared using TRIzol (Thermo Fisher Scientific, Inc.) according to the manufacturer's protocol. Single-stranded cDNA was synthesized from $1 \mu \mathrm{g}$ total RNA using a High Capacity cDNA Reverse Transcription kit (Thermo Fisher Scientific, Inc.). RT-qPCR was performed using Power 2X SYBR Real-time PCR Premixture (BioTek Instruments, Inc., Winooski, VT, USA) according to the manufacturer's protocol. The following primer sequences were used: RXR $\alpha$, forward, 5'-TCAAGCGCAGACAAGCAGC-3', and reverse, 5'-GCCAGGAGAATCCCATCT-3'; Nur77 forward, 5'-GAAGCTCAGGCAGTTTGC-3', and reverse, 5'-CGCTCT GGTCCTCATCAC-3'; GAPH, forward, 5'-AGCCTCCTT GATGGCCTCCTTG-3', and reverse, 5'-AGAACATCATTC CCAGCAGC-3'. PCR amplification was performed in a $25 \mu \mathrm{l}$ reaction containing $12.5 \mu \mathrm{l}$ of $2 \mathrm{X}$ Premix, $1 \mu \mathrm{l}$ forward and $1 \mu \mathrm{l}$ reverse primers, $1 \mu \mathrm{l}$ cDNA template, and $9.5 \mu \mathrm{ldd} \mathrm{d}_{2} \mathrm{O}$ under the following conditions: $94^{\circ} \mathrm{C}$ for $4 \mathrm{~min}$, followed by 40 cycles of $94^{\circ} \mathrm{C}$ for $15 \mathrm{sec}, 60.5^{\circ} \mathrm{C}$ for $60 \mathrm{sec}$, and $60.5^{\circ} \mathrm{C}$ for $30 \mathrm{sec}$. The relative quantity of mRNA expression was calculated using the $2^{-\Delta \Delta \mathrm{Cq}}$ method (26).

Immunohistochemistry and immunocytochemistry. Following perfusion with $4 \%$ paraformaldehyde/phosphate-buffered saline (PBS), mouse brains were cryopreserved in $30 \%(\mathrm{w} / \mathrm{v})$ sucrose/PBS at $4^{\circ} \mathrm{C}$ overnight. Brain samples embedded in optimal cutting temperature compound (Sangon Biotech Co., Ltd.) were divided into $20-\mu \mathrm{m}$ coronal sections and mounted on glass. Every tenth section was collected in sequential order (starting at bregma-1.46 $\mathrm{mm}$ ). The total number of sections was 4 per animal. Brain sections were blocked at room temperature for $1 \mathrm{~h}$ in a solution containing $10 \%$ normal goat serum (Sigma-Aldrich; Merck KGaA), 0.2\% Triton X-100 (Sangon Biotech Co., Ltd.) and 0.02\% NaN3 (Kegonghua Chemical Technology Co., Beijing, China) in Tris-buffered saline, and incubated with primary antibodies at $4^{\circ} \mathrm{C}$ overnight. Brain sections were then incubated with fluorescence-conjugated goat secondary antibodies for $1 \mathrm{~h}$. To visualize the nuclei, sections were counterstained with DAPI ( $2 \mu \mathrm{g} / \mathrm{ml}$; Invitrogen; Thermo Fisher Scientific, Inc.) for $5 \mathrm{~min}$ in the dark at room temperature. Following incubation with antibodies, sections were washed three times with PBS containing 0.5\% Tween-20 for 10 min each time. The sections were visualized using laser confocal microscopy (Leica TCS SP5, Leica Microsystems
$\mathrm{GmbH}$, Wetzlar, Germany). Acquired images were analyzed with Leica Application Suite X software 4.2 (version 4.2; Leica Microsystems $\mathrm{GmbH}$ ). A total of four visual fields (magnification, $\mathrm{x} 200$ ) of each coronary section were randomly selected, and a total of four sections from each animal were used for assessment.

For immunocytochemical analysis, drug-treated N2a cells $\left(2 \times 10^{5}\right.$ cells/well) were rinsed with PBS and fixed with $4 \%$ paraformaldehyde for $20 \mathrm{~min}$ at room temperature. $\mathrm{N} 2 \mathrm{a}$ cells were permeabilized in $0.1 \%$ Triton $\mathrm{X}-100$ for 25 min, and fixed N2a cells were blocked with $10 \%$ normal goat serum in PBS for $1 \mathrm{~h}$ at room temperature prior to incubation with primary antibodies at $4^{\circ} \mathrm{C}$ overnight. $\mathrm{N} 2$ a cells were then incubated with fluorescence-conjugated secondary antibodies at room temperature for $1 \mathrm{~h}$, and counterstained with DAPI to visualize the nuclei. A total of four visual fields (magnification, x200) of each section were randomly selected for visualization using laser confocal microscopy (Leica TCS SP5; Leica Microsystems GmbH) and assessment by using Leica Application Suite X software (version 4.2; Leica Microsystems GmbH). For immunohistochemical and immunocytochemical analysis, the primary antibodies used were rabbit anti-RXR $\alpha$ (cat. no. sc-553; 1:200; Santa Cruz Biotechnology, Inc.) and goat anti-Nur77 (cat. no. sc-7014; 1:200; Santa Cruz Biotechnology, Inc.). The secondary antibodies were goat anti-rabbit IgG DyLight ${ }^{\circledR} 594$ (cat. no. 35560; 1:200; Thermo Fisher Scientific, Inc.) and donkey anti-goat IgG DyLight ${ }^{\circledR} 488$ (cat. no. SA5-10086; 1:200; Thermo Fisher Scientific, Inc.).

MTT assays. The procedures were performed by using MTT Cell Proliferation and Cytotoxicity assay kit (Beyotime Institute of Biotechnology), according to the manufacturer's instructions. N2a cells were seeded onto 96 -well plates at a density of $2 \times 10^{3}$ cells/well, and cells were assigned to the following 3 groups as follows: The $A \beta_{25-35}$ treatment group, where cells were treated with $25 \mu \mathrm{mol} / 1 \mathrm{~A} \beta_{25-35}$ solution for $24 \mathrm{~h}$; the $\mathrm{A} \beta_{25-35}-9$-cis-RA treatment group, where cells were incubated in $0.1 \mu \mathrm{mol} / 1$ 9-cis-RA solution for $12 \mathrm{~h}$, followed by treatment with $25 \mu \mathrm{mol} / 1 \mathrm{~A} \beta_{25-35}$ solution for $12 \mathrm{~h}$; the control group, where cells were treated with the same volume of $\mathrm{ddH}_{2} \mathrm{O}$. The $\mathrm{N} 2 \mathrm{a}$ cells were maintained at $37^{\circ} \mathrm{C}$ in a humidified incubator with $5 \% \mathrm{CO}_{2}$ for $24 \mathrm{~h}$. MTT solution $(10 \mu \mathrm{l})$ was then added to each well, and cells were incubated for a further $4 \mathrm{~h}$. Formazan diluent solution $(100 \mu \mathrm{l})$ was subsequently added to each well, and the plates were placed in a humidified incubator with $5 \% \mathrm{CO}_{2}$ at $37^{\circ} \mathrm{C}$ until the purple formazan crystals were completely dissolved. Cell viability was measured using the absorbance value at $570 \mathrm{~nm}$ by using a BioTek ELx808 Absorbance Microplate reader (BioTek Instruments, Inc.).

Flow cytometric assay. Cell apoptosis was determined using an Annexin V-FITC Apoptosis kit (BioVision, Inc., Milpitas, CA, USA). N2a cells were seeded onto 6-well plates at a density of $1 \times 10^{5}$ cells/well and were assigned to the following 3 groups: The $A \beta_{25-35}$ treatment group, where cells were treated with $25 \mu \mathrm{mol} / 1 \mathrm{~A} \beta_{25-35}$ solution for $24 \mathrm{~h}$; the $\mathrm{A} \beta_{25-35}-9$-cis-RA treatment group, where cells were incubated in $0.1 \mu \mathrm{mol} / 19$-cis-RA solution for $12 \mathrm{~h}$, followed by treatment with $25 \mu \mathrm{mol} / 1 \mathrm{~A} \beta_{25-35}$ solution for $12 \mathrm{~h}$; the control group, where cells were treated 
A

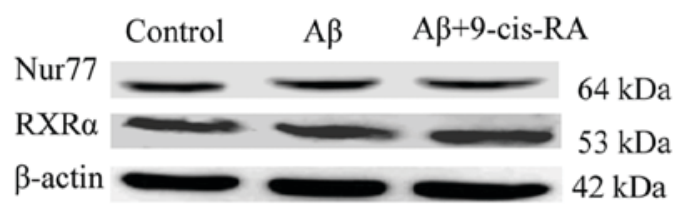

C

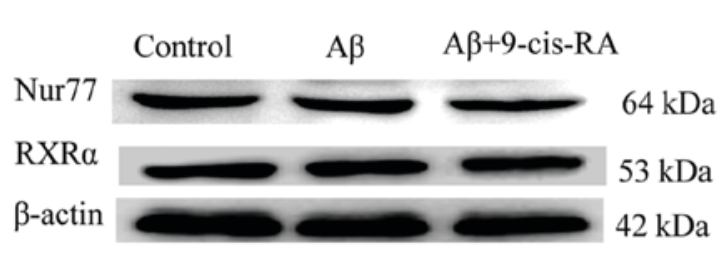

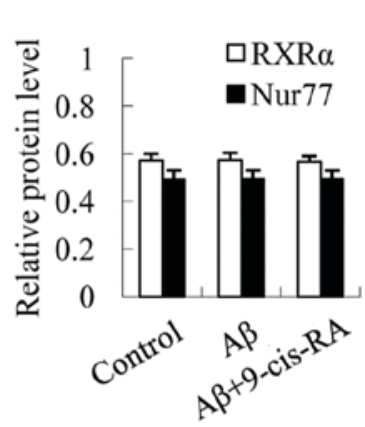

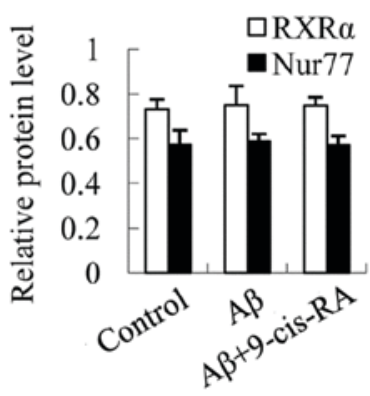

B
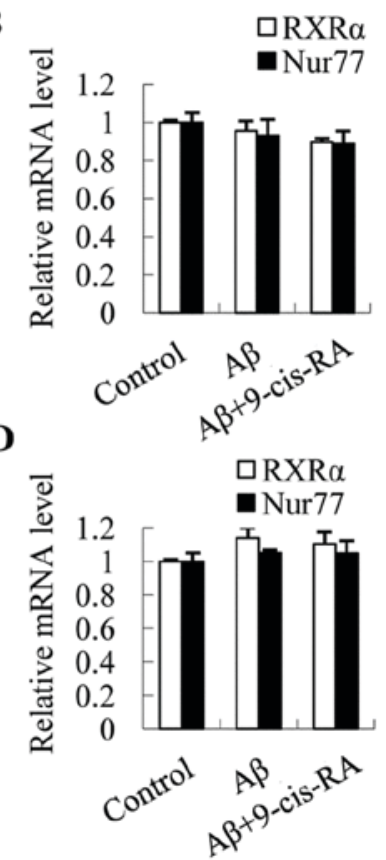

Figure 1. RXR $\alpha$ and Nur77 (A) protein and (B) mRNA expression levels in Neuro 2a cells, and the (C) protein and (D) mRNA expression levels of these factors in C57BL/6 mouse hippocampi. Data are representative of three independent experiments, and are expressed as the mean \pm standard deviation. RXR $\alpha$, retinoid $\mathrm{X}$ receptor- $\alpha$.

with the same volume of $\mathrm{ddH}_{2} \mathrm{O}$. The $\mathrm{N} 2 \mathrm{a}$ cells were maintained at $37^{\circ} \mathrm{C}$ in a humidified incubator with $5 \% \mathrm{CO}_{2}$ for $24 \mathrm{~h}$ before they were harvested. Cells were subsequently rinsed in cool PBS, and re-suspended in $250 \mu \mathrm{l}$ binding buffer (1X). A total of $100 \mu \mathrm{l}$ cell suspension (cell density of $1 \times 10^{5}$ cells/well) was transferred to a $5 \mathrm{ml}$ tube, and $5 \mu \mathrm{l}$ Annexin V-fluorescein isothiocyanate and $5 \mu \mathrm{l}$ propidium iodide was added, mixed and incubated in the dark at room temperature for $15 \mathrm{~min}$. A total of $400 \mu$ l binding buffer (1X) was then added, and apoptosis of N2a cells was analyzed using an EPICS Altra Flow Cytometer (Beckman Coulter, Inc.; Brea, CA, USA) and CellQuest software (version 5.1; Beckman Coulter, Inc.).

Statistical analysis. Data are expressed as the mean \pm standard deviation, and statistical analyses were performed using GraphPad Prism 5 (GraphPad Software, Inc., La Jolla, CA, USA). Differences between the means of groups were tested for statistical significance using the one-way analysis of variance followed by Tukey's multiple comparisons test. $\mathrm{P}<0.05$ was considered to indicate a statistically significant difference.

\section{Results}

$A \beta_{25-35}$ treatment demonstrates no significant effect on $R X R \alpha$ and Nur77 expression. In order to evaluate the effect of $A \beta_{25-35}$ treatment on the expression of RXR $\alpha$ and Nur77, N2a cells were treated with $25 \mu \mathrm{mol} / 1 \mathrm{~A} \beta_{25-35}$ alone or in combination with $0.1 \mu \mathrm{mol} / 1$ 9-cis-RA, while untreated cells served as controls. Western blotting and RT-qPCR analyses revealed comparative protein and mRNA expression levels of RXR $\alpha$ and Nur77 relative to the controls (Fig. 1). These results indicated that treatment with $\mathrm{A} \beta_{25-35}$ alone or in combination with 9-cis-RA demonstrated no significant effect on the expression levels of RXR $\alpha$ and Nur77, at the translational (Fig. 1A) or transcriptional levels (Fig. 1B). In addition, mouse hippocampi were injected with $2 \mu \mathrm{g} \mathrm{A} \beta_{25-35}$ or $2 \mu \mathrm{g} \mathrm{A} \beta_{25-35}$ combined with $1 \mu \mathrm{g}$ 9-cis-RA, while untreated mice served as controls. No significant difference in the expression of $\operatorname{RXR} \alpha$ and Nur77 among the three experimental groups at the translational (Fig. 1C) or transcriptional (Fig. 1D) levels were observed, indicating that treatment with $A \beta_{25-35}$ alone or $A \beta_{25-35^{-}}$-cis-RA combination demonstrated no significant effects on $\mathrm{RXR} \alpha$ and Nur77 mRNA and protein expression levels.

Nuclear-cytoplasmic translocation of $R X R \alpha$ is required for cytoplasmic targeting of Nur77 in N2a cells and the mouse hippocampus. RXR $\alpha$ and Nur77 are primarily located in the nuclei of untreated $\mathrm{N} 2$ a cells, and the cytoplasmic protein ratios of RXR $\alpha$ and Nur77 were 5.26 and $4.85 \%$, respectively (Fig. 2A). Treatment of N2a cells with $25 \mu \mathrm{mol} / 1$ $\mathrm{A} \beta_{25-35}$ for $24 \mathrm{~h}$ resulted in significantly reduced $\mathrm{RXR} \alpha$ and Nur77 expression in the nucleus (Fig. 2A) and significantly elevated expression in the cytoplasm when compared with the controls (RXR $\alpha$, 8.41-fold, $\mathrm{P}<0.001$; Nur77, 7.33-fold, $\mathrm{P}<0.001$; Fig. 2A). In order to investigate whether $\mathrm{RXR} \alpha$ nuclear export is required for Nur77 cytoplasmic targeting in neurons, N2a cells were pretreated with $0.1 \mu \mathrm{mol} / 1$ 9-cis-RA or control medium for $12 \mathrm{~h}$, followed by treatment with $25 \mu \mathrm{mol} / 1 \mathrm{~A} \beta_{25-35}$ for $24 \mathrm{~h}$. Western blot analysis demonstrated that the cytoplasmic protein ratios of RXR $\alpha$ and Nur77 were significantly reduced in the $A \beta_{25-35}-9$-cis-RA group compared with $\mathrm{A} \beta_{25-35}$-treated N2a cells [RXR $\alpha, \mathrm{A} \beta_{25-35}(42.22 \%)$ vs. $A \beta_{25-35}$-9-cis-RA (6.67\%), $\mathrm{P}<0.001 ; \mathrm{Nur77}, \mathrm{A} \beta_{25-35}(35.49 \%)$ vs. $\mathrm{A} \beta_{25-35}-9$-cis-RA (5.44\%), $\mathrm{P}<0.001$; Fig. $\left.2 \mathrm{~A}\right]$. Confocal microscopy revealed that Nur77 and RXR $\alpha$ proteins were predominantly localized in the nuclei of untreated N2a cells, 


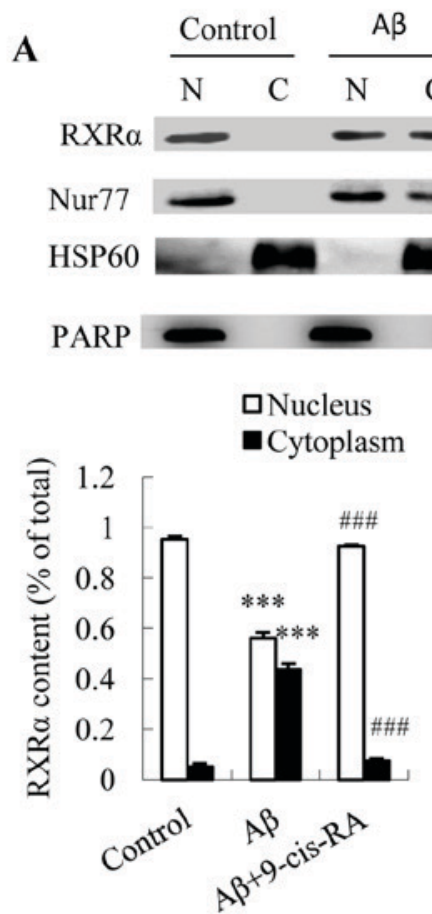

$\frac{A \beta+9-\text { cis- } R A}{N \quad C}$

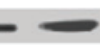

$53 \mathrm{kDa}$

$64 \mathrm{kDa}$

$60 \mathrm{kDa}$

$110 \mathrm{kDa}$
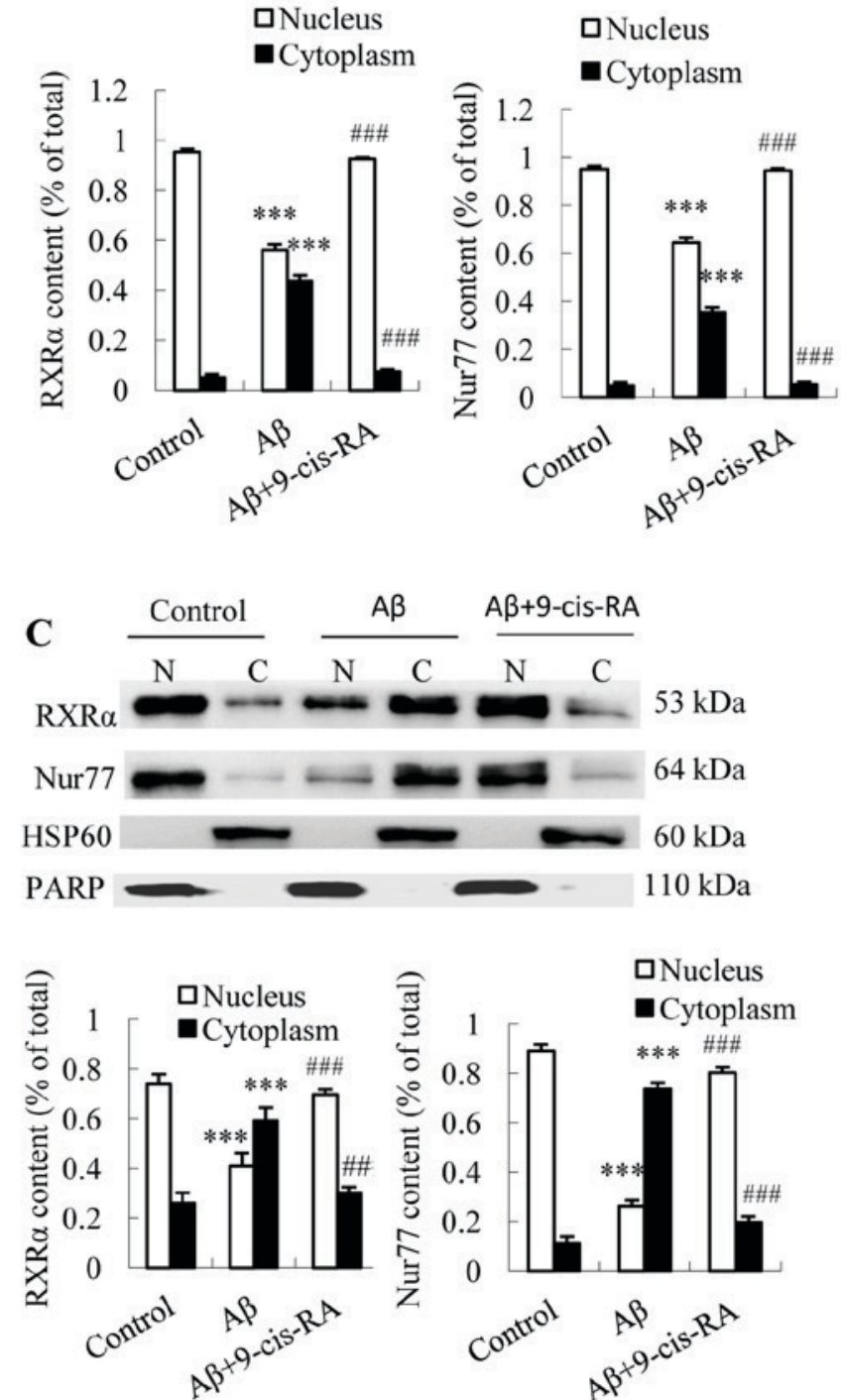
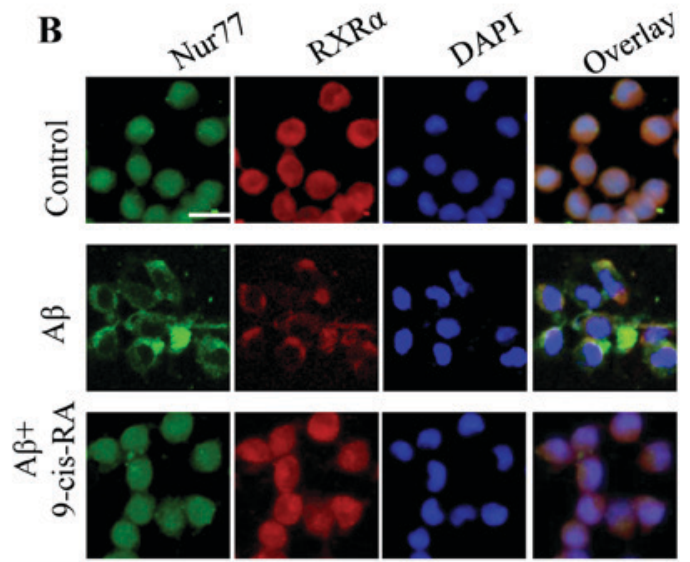

Figure 2. Effect of $A \beta_{25-35}$ treatment or $A \beta_{25-35}$ plus 9-cis-RA treatment on the cellular location of RXR $\alpha$ and Nur77 in N2a cells and the mouse hippocampus. (A) RXR $\alpha$ and Nur77 nuclear and cytoplasmic protein expression in N2a cells, normalized to the expression of cytoplasmic protein HSP60 and nuclear protein PARP (n=3). (B) Representative fluorescence microscope images showing immunocytochemical staining of RXR $\alpha$ and Nur77 expression in N2a cells (scale bar, $10 \mu \mathrm{m}$ ). (C) RXR $\alpha$ and Nur77 nuclear and cytoplasmic protein expression in mouse hippocampus tissue was normalized to the expression of cytoplasmic protein HSP60 and nuclear protein PARP (n=5). (D) Representative fluorescence microscope images showing immunohistochemical staining of RXR $\alpha$ and Nur77 in the CA1 region of C57BL/6 mouse hippocampi (scale bar, $10 \mu \mathrm{m}$ ). Values are presented as the mean \pm standard deviation of $\geq 3$ independent experiments. ${ }^{*} \mathrm{P}<0.05,{ }^{* *} \mathrm{P}<0.01$ and ${ }^{* * *} \mathrm{P}<0.001$ vs. control group; ${ }^{\#} \mathrm{P}<0.05,{ }^{\# \#} \mathrm{P}<0.01$ and ${ }^{\# \# \#} \mathrm{P}<0.001$ vs. A $\beta$ group. A $\beta, \beta$-amyloid; 9 -cis-RA, 9 -cis-retinoid acid; $\mathrm{RXR} \alpha$, retinoid $X$ receptor- $\alpha$; N2a, Neuro-2a; HSP60, heat shock protein 60; PARP, poly(ADP-ribose) polymerase.

while RXR $\alpha$ and Nur77 were predominantly co-localized in the cytoplasm of $A \beta_{25-35}$-treated N2a cells (Fig. 2B). In addition, the distribution of RXR $\alpha$ and Nur77 overlapped, suggesting an interaction between RXR $\alpha$ and Nur77 in the cytoplasm (Fig. 2B). However, the nuclear export of RXR $\alpha$ and Nur77 was visibly inhibited in N2a cells treated with $\mathrm{A} \beta_{25-35}$ plus 9-cis-RA (Fig. 2B).
The dependence of the cytoplasmic localization of Nur77 on $\mathrm{RXR} \alpha$ localization in vivo was then evaluated. The hippocampi of C57BL/6 mice were injected with $2 \mu \mathrm{g} \mathrm{A} \beta_{25-35}$ or $2 \mu \mathrm{g} \mathrm{A} \beta_{25-35}$ plus $1 \mu \mathrm{g}$ 9-cis-RA for $24 \mathrm{~h}$, while sham-operated mice served as controls. Western blotting analysis revealed that $A \beta_{25-35}$ treatment was associated with a marked increase in the translocation of RXR $\alpha$ and Nur77 from the nucleus to the cytoplasm 


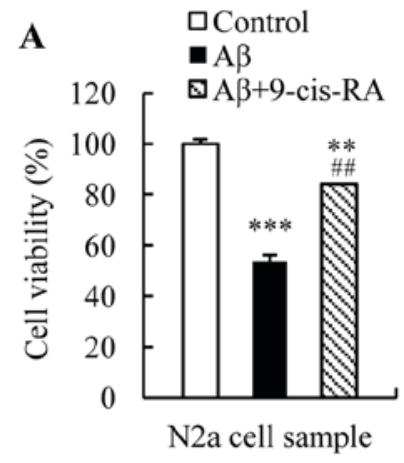

B
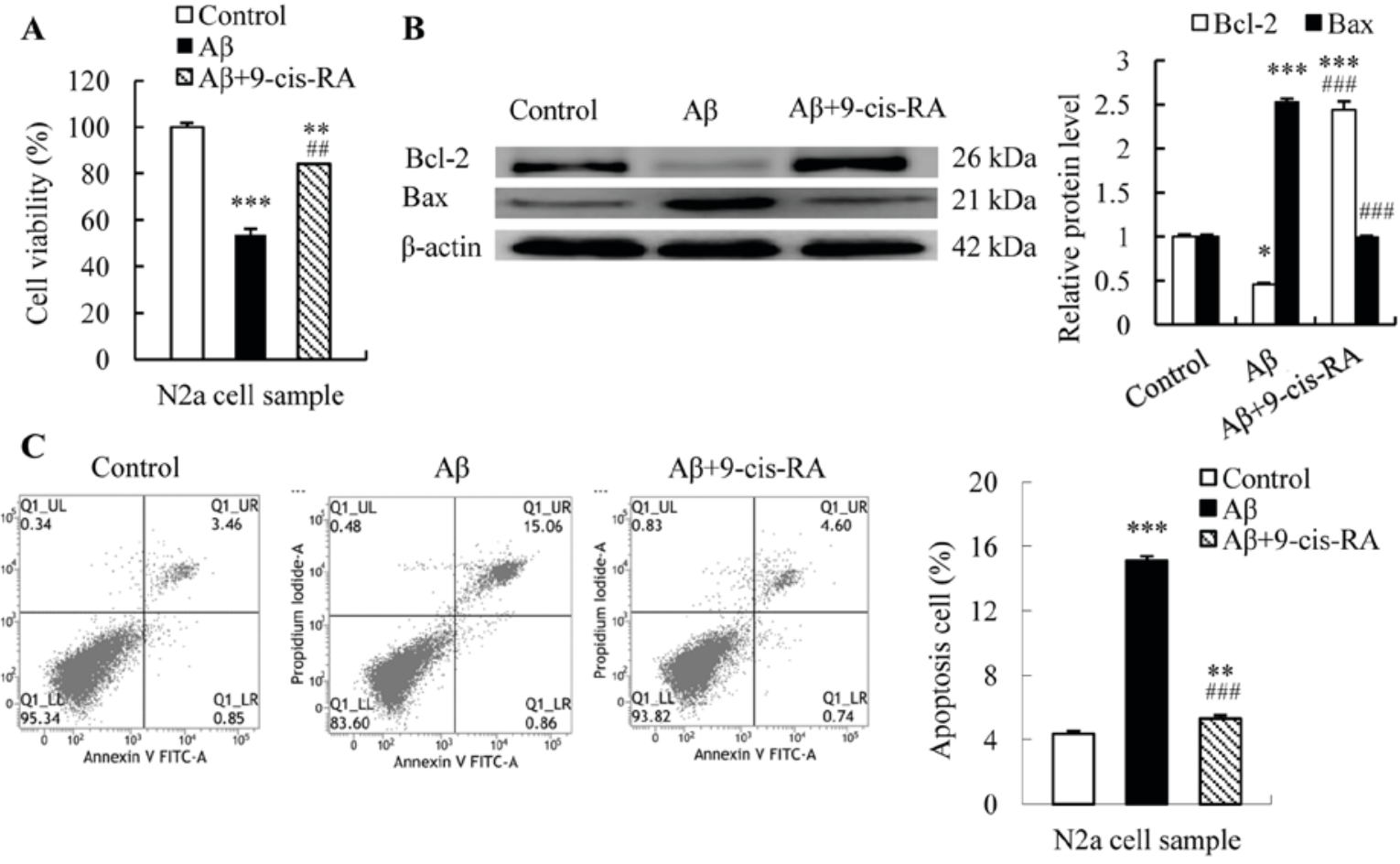

Figure 3. 9-cis-RA induces cell proliferation and inhibits apoptosis of N2a cells in the presence of A $\beta_{25-35 .}$. A) N2a cell viability, as determined using an MTT assay. (B) Western blotting analysis and quantification of Bcl-2 and Bax protein expression levels. (C) The apoptosis rate of N2a cells as determined by flow cytometry analysis. Data are representative of three independent experiments, and values are presented as the mean \pm standard deviation. ${ }^{*} \mathrm{P}<0.05,{ }^{* *} \mathrm{P}<0.01$ and ${ }^{* * * *} \mathrm{P}<0.001$ vs. control group; ${ }^{\#} \mathrm{P}<0.05$, ${ }^{\#} \mathrm{P}<0.01$ and ${ }^{\# \#} \mathrm{P}<0.001$ vs. A $\beta$ group. 9-cis-RA, 9-cis-retinoid acid; N2a, Neuro-2a; $\mathrm{A} \beta, \beta$-amyloid; Bcl-2, $\mathrm{B}$ cell lymphoma-2; Bax, Bcl-2 associated $\mathrm{X}$.

of hippocampus cells, and RXR $\alpha$ and Nur77 protein expression increased from 26.1 and $11.1 \%$ to 59.2 and $73.7 \%$, respectively, in the cytoplasm relative to the controls $(\mathrm{P}<0.001$ and $\mathrm{P}<0.001$, respectively; Fig. 2C). In addition, the cytoplasmic protein ratios of RXR $\alpha$ and Nur77 decreased from 59.2 and $73.7 \%$ in the hippocampal tissues of $A \beta_{25-35}$-treated mice to 30.2 and $19.8 \%$ in $\mathrm{A} \beta_{25-35}$ plus 9-cis-RA co-treated mice, respectively, when compared with mice treated with $A \beta_{25-35}$ alone $(\mathrm{P}<0.01$ and $\mathrm{P}<0.001$, respectively; Fig. 2C). Confocal microscopy revealed that $\mathrm{RXR} \alpha$ and Nur77 were primarily localized to the nucleus and the nuclear periphery of untreated mice, while an increase in RXR $\alpha$ and Nur77 fluorescence in the cytoplasm of $\mathrm{A} \beta_{25-35}$-treated mice was observed (Fig. 2D). In the mice treated with $2 \mu \mathrm{g} \mathrm{A} \beta_{25-35}$ plus $1 \mu \mathrm{g}$ 9-cis-RA, RXR $\alpha$ and Nur77 were observed to reside in the nucleus and nuclear periphery when compared with the $\mathrm{A} \beta_{25-35}$ treatment group (Fig. 2D).

9-cis-RA improves cell viability and inhibits apoptosis of $N 2$ a cells in the presence of $A \beta_{25-35}$. The results of the MTT assay revealed a significant reduction in the viability of $\mathrm{N} 2 \mathrm{a}$ cells following treatment with $A \beta_{25-35}$ for $24 \mathrm{~h}$ when compared with the controls (from 100 to $53.65 \%$ cell viability; $\mathrm{P}<0.001$; Fig. 3A). By contrast, the viability of $\mathrm{N} 2$ a cells treated with $\mathrm{A} \beta_{25-35}$ plus 9-cis-RA significantly increased from 53.65 to $84.10 \%\left(\mathrm{P}<0.01\right.$ vs. $\mathrm{A} \beta_{25-35}$-treated cells; Fig. 3A).

Mitochondrial outer membrane permeabilization, which is involved in the induction of apoptosis, is controlled by proand anti-apoptotic factors (27). Therefore, the expression of mitochondrial membrane permeabilization factors Bcl-2 and Bax was examined in the present study. N2a cells were treated with $25 \mu \mathrm{mol} / 1 \mathrm{~A} \beta_{25-35}$ for $24 \mathrm{~h}$ alone or in combination with $0.1 \mu \mathrm{mol} / 1 \mathrm{9}$-cis-RA for $12 \mathrm{~h}$, while untreated cells served as controls. Bcl-2 and Bax protein expression levels were subsequently quantified. Western blotting analysis revealed elevated Bax expression and reduced Bcl-2 expression (Bax, 2.52-fold, $\mathrm{P}<0.001$; Bcl-2, 0.46-fold, $\mathrm{P}<0.05$; Fig. 3B) in $\mathrm{A} \beta_{25-35}$-treated $\mathrm{N} 2 \mathrm{a}$ cells when compared with controls. Combined treatment with $\mathrm{A} \beta_{25-35}$ and 9-cis-RA recovered $\mathrm{Bcl}-2$ expression from 0.46-fold in $A \beta_{25-35}$-treated cells to 2.44-fold relative to controls $(\mathrm{P}<0.001$; Fig. 3B), and decreased Bax expression from 2.52-fold in $A \beta_{25-35}$-treated cells to 0.99-fold relative to controls $(\mathrm{P}<0.001$; Fig. 3B).

Flow cytometry analysis revealed that the apoptotic rate of untreated $\mathrm{N} 2$ a cells was $4.36 \%$, while an apoptotic rate of $15.1 \%$ was detected in cells cultured in the presence of $25 \mu \mathrm{mol} / 1 \mathrm{~A} \beta_{25-35}$ for $24 \mathrm{~h}(\mathrm{P}<0.001$; Fig. 3C). In addition, combined treatment with $25 \mu \mathrm{mol} / 1 \mathrm{~A} \beta_{25-35}$ plus $0.1 \mu \mathrm{mol} / 1$ 9-cis-RA resulted in a $\sim 5.31 \%$ apoptotic rate, which was a significant reduction when compared with cells treated with $\mathrm{A} \beta_{25-35}$ alone $(\mathrm{P}<0.001$; Fig. 3C).

\section{Discussion}

$\mathrm{A} \beta$ accumulation is generally accepted to be critical for the development of AD dementia $(28,29)$. A $\beta$ has been confirmed to exhibit neurotoxic effects on neurons (30). In the present study, an increased apoptotic rate of $\mathrm{A} \beta_{25-35}$-treated N2a cells was observed, and cell viability decreased when compared with untreated controls. These results are consistent with the notion that $A \beta$ is toxic to neurons. However, these results were 
obtained from cell and animal experiments, and further human studies are therefore required to validate this conclusion.

Modulation of RXR $\alpha$ levels has been previously reported to directly affect $A \beta$ generation (25). Given the involvement of RXR $\alpha /$ Nur77 in the regulation of cell death, the effect of $\mathrm{A} \beta_{25-35}$ treatment on RXR $\alpha$ and Nur77 expression at translational and transcriptional levels was investigated in the present study. Western blotting and RT-qPCR analysis revealed no significant difference in the protein and mRNA levels of RXR $\alpha$ and Nur77 between the $A \beta_{25-35}$-treated and untreated control groups. This is inconsistent with the report demonstrating that higher levels of RXR $\alpha$ gene expression occur in AD (19). It is possible that a single injection was insufficient to alter $\mathrm{RXR} \alpha$ expression significantly.

RXR $\alpha$ has been demonstrated to regulate Nur77-dependent apoptosis by modulating Nur77 nuclear export (8). However, the involvement of $\mathrm{RXR} \alpha$ in the regulation of neuronal apoptosis is unclear. In the present study, this potential function of $\mathrm{RXR} \alpha$ was confirmed using in vivo and in vitro experimental systems, which mimic the pathologic condition of AD. In response to $\mathrm{A} \beta_{25-35}$ stimulation RXR $\alpha /$ Nur77 were co-transported into the cytoplasm in $\mathrm{N} 2$ a cells and hippocampal neurons, as the rate of apoptosis increased. Further studies to validate the co-localization of RXR $\alpha /$ Nur77 in mitochondria and investigate the mechanisms underlying the association between RXR $\alpha /$ Nur77 nuclear export and apoptosis are required.

In the present study, the role of $\mathrm{RXR} \alpha$ nuclear export in mediating Nur77 nuclear export was investigated. In the presence of 9-cis-RA, A $\beta_{25-35}$-induced RXR $\alpha /$ Nur77 nuclear export was inhibited both in vivo and in vitro. The results of the present study provide some evidence to suggest that Nur77 may be transported to the cytoplasm via its interaction with RXR $\alpha$, which is consistent to a previous report (14). The pro-apoptotic Bax and anti-apoptotic $\mathrm{Bcl}-2$ protein expression levels were then analyzed. $A \beta_{25-35}$ treatment was demonstrated to result in elevated Bax expression and reduced Bcl-2 expression, accompanied by RXR $\alpha /$ Nur77 nuclear export and an increased apoptotic rate in N2a cells. The expression of Bax and Bcl-2 was consistent with previous observations that $\mathrm{Bcl}-2$ inhibits apoptosis and $\mathrm{Bax}$ promotes apoptosis (31). However, treatment with 9-cis-RA plus $\mathrm{A} \beta_{25-35}$ resulted in a decreased apoptotic rate of N2a cells, and inhibition of RXR $\alpha /$ Nur77 nuclear export coincided with the decreased Bax and increased Bcl-2 expression. These results suggested that $\mathrm{A} \beta$-induced RXR $\alpha$ and Nur77 co-translocation was associated with the alterations in $\mathrm{Bcl}-2$ and Bax expression, which may have initiated apoptosis in neurons.

In conclusion, the results of the present study demonstrated that $A \beta$-mediated neuronal death may be dependent on Nur77, and $\mathrm{RXR} \alpha$ and its ligands may be involved in regulating Nur77-dependent apoptosis in neurons. Elucidation of the mechanisms underlying the inhibition of RXR $\alpha$ translocation may be of significance for the development of anti-AD agents that suppress neuronal apoptosis.

\section{Acknowledgements}

The present study was supported by the grants from the Special Funds of the National Natural Science Foundation of China (grant no. 81241017), the Science and Technology Project of Fujian Provincial Department of Education (grant no. JA11109), and the Academic Development Funds for the Professors in Fujian Medical University (grant no. JS/4003).

\section{References}

1. Querfurth HW and LaFerla FM: Alzheimer's disease. N Engl J Med 362: 329-344, 2010.

2. Brookmeyer R, Johnson E, Ziegler-Graham K and Arrighi HM: Forecasting the global burden of Alzheimer's disease. Alzheimers Dement 3: 186-191, 2007.

3. Ballard C, Gauthier S, Corbett A, Brayne C, Aarsland D and Jones E: Alzheimer's disease. Lancet 377: 1019-1031, 2011.

4. Gandy S and DeKosky ST: Toward the treatment and prevention of Alzheimer's disease: Rational strategies and recent progress. Annu Rev Med 64: 367-383, 2013.

5. Mattson MP: Apoptosis in neurodegenerative disorders. Nat Rev Mol Cell Biol 1: 120-129, 2000.

6. Morishima Y, Gotoh Y, Zieg J, Barrett T, Takano H, Flavell R, Davis RJ, Shirasaki Y and Greenberg ME: Beta-amyloid induces neuronal apoptosis via a mechanism that involves the c-Jun $\mathrm{N}$-terminal kinase pathway and the induction of Fas ligand. J Neurosci 21: 7551-7560, 2001.

7. Favaloro B, Allocati N, Graziano V, Di Ilio C and De Laurenzi V: Role of apoptosis in disease. Aging (Albany NY) 4: 330-349, 2012.

8. Muradian K and Schachtschabel DO: The role of apoptosis in aging and age-related disease: Update. Z Gerontol Geriatr 34: 441-446, 2001.

9. He H, Dong W and Huang F: Anti-amyloidogenic and anti-apoptotic role of melatonin in Alzheimer disease. Curr Neuropharmacol 8: 211-227, 2010.

10. Tait SW and Green DR: Mitochondria and cell death: Outer membrane permeabilization and beyond. Nat Rev Mol Cell Biol 11: 621-632, 2010.

11. Dai Y, Zhang W, Sun Q, Zhang X, Zhou X, Hu Y and Shi J: Nuclear receptor nur77 promotes cerebral cell apoptosis and induces early brain injury after experimental subarachnoid hemorrhage in rats. J Neurosci Res 92: 1110-1121, 2014.

12. Moll UM, Marchenko $\mathrm{N}$ and Zhang XK: p53 and Nur77/TR3-transcription factors that directly target mitochondria for cell death induction. Oncogene 25: 4725-4743, 2006.

13. Lin B, Kolluri SK, Lin F, Liu W, Han YH, Cao X, Dawson MI, Reed JC and Zhang XK: Conversion of Bcl-2 from protector to killer by interaction with nuclear orphan receptor Nur77/TR3. Cell 116: 527-540, 2004.

14. Lin XF, Zhao BX, Chen HZ, Ye XF, Yang CY, Zhou HY, Zhang MQ, Lin SC and Wu Q: RXR alpha acts as a carrier for TR3 nuclear export in a 9-cis retinoic acid-dependent manner in gastric cancer cells. J Cell Sci 117: 5609-5621, 2004.

15. Zhang XK, Su Y, Chen L, Chen F, Liu J and Zhou H: Regulation of the nongenomic actions of retinoid $\mathrm{X}$ receptor- $\alpha$ by targeting the coregulator-binding sites. Acta Pharmacol Sin 36: 102-112, 2015.

16. Salerno AJ, He Z, Goos-Nilsson A, Ahola H and Mak P: Differential transcriptional regulation of the apoAI gene by retinoic acid receptor homo- and heterodimers in yeast. Nucleic Acids Res 24: 566-572, 1996.

17. Lefebvre P, Benomar Y and Staels B: Retinoid X receptors: Common heterodimerization partners with distinct functions. Trends Endocrinol Metab 21: 676-683, 2010.

18. Cao X, Liu W, Lin F, Li H, Kolluri SK, Lin B, Han YH, Dawson MI and Zhang XK: Retinoid X receptor regulates Nur77/TR3-dependent apoptosis [corrected] by modulating its nuclear export and mitochondrial targeting. Mol Cell Biol 24: 9705-9725, 2004.

19. Akram A, Schmeidler J, Katsel P, Hof PR and Haroutunian V: Increased expression of $\mathrm{RXR} \alpha$ in dementia: A nearly harbinger for the cholesterol dyshomeostasis? Mol Neurodegener 5: 36, 2010.

20. Kiss B, Tóth K, Sarang Z, Garabuczi É and Szondy Z: Retinoids induce Nur77-dependent apoptosis in mouse thymocytes. Biochim Biophys Acta 1853: 660-670, 2015.

21. Cunningham NR, Artim SC, Fornadel CM, Sellars MC, Edmonson SG, Scott G, Albino F, Mathur A and Punt JA: Immature $\mathrm{CD} 4{ }^{+} \mathrm{CD} 8$ + thymocytes and mature $\mathrm{T}$ cells regulate Nur77 distinctly in response to TCR stimulation. J Immunol 177: 6660-6666, 2006.

22. Wu Q, Liu S, Ye XF, Huang ZW and Su WJ: Dual roles of Nur77 in selective regulation of apoptosis and cell cycle by TPA and ATRA in gastric cancer cells. Carcinogenesis 23: 1583-1592, 2002. 
23. Yu H, Kumar SM, Fang D, Acs G and Xu X: Nuclear orphan receptor TR3/Nur77 mediates melanoma cell apoptosis. Cancer Biol Ther 6: 405-412,2007.

24. Suzuki S, Suzuki N, Mirtsos C, Horacek T, Lye E, Noh SK, Ho A, Bouchard D, Mak TW and Yeh WC: Nur77 as a survival factor in tumor necrosis factor signaling. Proc Natl Acad Sci USA 100: 8276-8280, 2003.

25. You X, Zhang YW, Chen Y, Huang X, Xu R, Cao X, Chen J, Liu Y, Zhang X and Xu H: Retinoid X receptor-alpha mediates (R)-flurbiprofen's effect on the levels of Alzheimer's beta-amyloid. J Neurochem 111: 142-149, 2009.

26. Livak KJ and Schmittgen TD: Analysis of relative gene expression data using real-time quantitative PCR and the 2(-Delta Delta C(T)) method. Methods 25: 402-408, 2001

27. Gillies LA and Kuwana T: Apoptosis regulation at the mitochondrial outer membrane. J Cell Biochem 115: 632-640, 2014

28. Haass C and Selkoe DJ: Soluble protein oligomers in neurodegeneration: Lessons from the Alzheimer's amyloid beta-peptide. Nat Rev Mol Cell Biol 8: 101-112, 2007.
29. Watson D, Castaño E, Kokjohn TA, Kuo YM, Lyubchenko Y, Pinsky D, Connolly ES Jr, Esh C, Luehrs DC, Stine WB, et al: Physicochemical characteristics of soluble oligomeric Abeta and their pathologic role in Alzheimer's disease. Neurol Res 27: 869-881, 2005.

30. Mucke L and Selkoe DL: Neurotoxicity of amyloid $\beta$-protein: synaptic and network dysfunction. Cold Spring Harb Perspect Med 2: a006338, 2012

31. Basu A and Haldar S: The relationship between BcI2, Bax and p53: Consequences for cell cycle progression and cell death. Mol Hum Reprod 4: 1099-1109, 1998. 